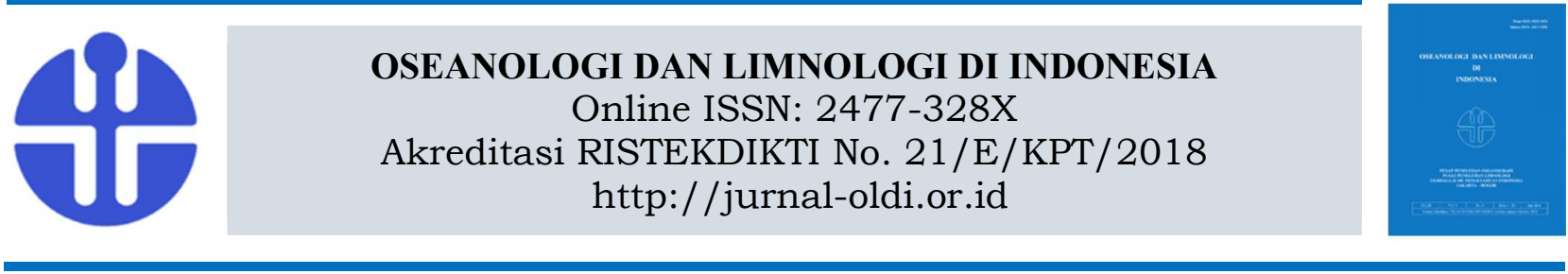

\title{
Color Alteration and Growth Performance of Spiny Lobster (Panulirus homarus) Juveniles Fed with Different Spirulina Concentration in Formulated Diet
}

\author{
Fawzan Bhakti Soffa ${ }^{1}$, Idham Sumarto Pratama ${ }^{1}$, Asep Ridwanudin ${ }^{1}$ and Varian Fahmi ${ }^{1}$ \\ ${ }^{1}$ Research and Development Division for Marine Bio Industry - Indonesian Institute of Sciences (LIPI), \\ Jalan Raya Senggigi, Lombok Utara, Nusa Tenggara Barat, Indonesia \\ Email: fawzanbhaktisoffa@gmail.com
}

Submitted 24 April 2019. Reviewed 15 May 2019. Accepted 30 July 2019.

DOI: 10.14203/oldi.2019.v4i2.265

\begin{abstract}
Spiny lobster Panulirus homarus is susceptible to color alteration in captivity, and it might affect market acceptance. Spirulina is known as carotenoids source that is required for pigmentation, growth performance and survival of spiny lobster. This study addressed the effect of Spirulina inclusion in the diet of juveniles $P$. homarus to minimize color alteration and improve growth performance. This study was performed in Aquaculture Laboratory of the Research and Development Division for Marine Bio Industry - Indonesian Institute of Sciences (LIPI), Lombok Utara, NTB, Indonesia. Three replicates of three formulated feeds $(0 \%$, $4 \%$ and $8 \%$ Spirulina inclusion) and one replicate of natural feed (minced trash fish, TF) were applied to juveniles of $P$. homarus. Juveniles were individually weighed and photographed to determine growth performance and color alteration in six body parts on carapace and abdomen using HSV (hue, saturation, value) color quantification method. After 97 days of the rearing period, changes in body color detected in all body parts of $P$. homarus compared to initial color. The inclusion of Spirulina in the formulated diet did not affect specific growth rate and the weight gain of spiny lobster. However, the survival rate of spiny lobster fed formulated diets were better than trash fish diet. In conclusion, although the inclusion of Spirulina in the formulated diet did not enhance significantly either the pigmentation level or the growth performance of spiny lobster, utilization of the formulated diet in spiny lobster culture are potential to prevent alteration of the body color and also the mortality of $P$. homarus during rearing period.
\end{abstract}

Keywords: Spirulina, juvenile, Panulirus homarus, diet, color

\begin{abstract}
Abstrak
Perubahan Warna dan Performa Pertumbuhan Juvenil Lobster Pasir (Panulirus homarus) yang diberi Pakan Buatan dengan Konsentrasi Spirulina Berbeda. Lobster pasir Panulirus homarus yang dibudidayakan rentan mengalami perubahan warna menjadi lebih pucat, sehingga dapat memengaruhi tingkat penerimaan konsumen terhadap produk tersebut di pasaran. Spirulina merupakan salah satu sumber karotenoid yang dibutuhkan lobster dalam proses pigmentasi, pertumbuhan dan kelangsungan hidup. Tujuan dari penelitian ini adalah untuk mengetahui pengaruh penambahan Spirulina dalam pakan buatan terhadap perubahan warna tubuh dan performa pertumbuhan pada juvenile lobster pasir. Penelitian dilakukan di Laboratorium Budidaya Balai Bio Industri Laut-LIPI, Lombok Utara, Nusa Tenggara Barat. Perlakuan penambahan tepung Spirulina dengan konsentrasi berbeda (0\%, 4\% dan 8\%) pada pakan buatan dilakukan sebanyak tiga ulangan, sedangkan perlakuan pakan rucah sebagai kontrol dilakukan tanpa ulangan. Setiap biota uji ditimbang dan difoto untuk dapat diamati tingkat pertumbuhannya serta perubahan warna yang terjadi di enam bagian tubuhnya menggunakan metode kuantifikasi warna HSV (hue, saturation, value).
\end{abstract}


Soffa et al.

Setelah 97 hari pemeliharaan, warna seluruh bagian tubuh lobster mengalami perubahan menjadi lebih cerah dibandingkan warna awal juvenil. Jika dibandingkan dengan perlakuan ikan rucah, perlakuan pakan dengan tambahan Spirulina berhasil meningkatkan rasio kelulushidupan namun tidak memengaruhi laju pertumbuhan spesifik serta pertambahan berat tubuh biota uji. Meskipun penambahan Spirulina tidak memberikan pengaruh yang signifikan terhadap pigmentasi dan pertumbuhan, penggunaan pakan buatan dalam budidaya lobster pasir memiliki potensi yang besar dalam mencegah perubahan warna dan mengurangi tingkat kematian selama pemeliharaan.

Kata kunci: Spirulina, juvenil, Panulirus homarus, pakan, warna

\section{Introduction}

Color can change market acceptance of the seafood commodities. Darker color seafood is more expensive than the pale color (Melville-Smith et al., 2003; Barclay et al., 2006; Tume et al., 2009). One of the expensive seafood, the spiny lobster Panulirus cygnus, has different price between 'red' or colored lobsters and 'white' or pale-colored lobsters. The difference of market value between those two lobsters are up to AU $\$ 3.00 / \mathrm{kg}$ (MelvilleSmith et al., 2003). In addition, the market price for highly pigmented black tiger prawn Penaeus monodon is up to AU $\$ 4.00 / \mathrm{kg}$ higher than fadedcolored prawn (Tume et al., 2009). It has been known that changing body color in the crustaceans into pale color was influenced by rearing conditions (Parisenti et al., 2011; Wade et al., 2012; Diaz-Jimenez et al., 2018). With regard to increasing pigmentation level, highly pigmented crustaceans can be achieved through decreasing depth, increasing light intensity, darkening the substrate and pigment supplements in diet (D'abramo et al., 1983; Tseng et al., 1998; Rao, 2001; Chien \& Shiau 2005; You et al., 2006; Wade et al., 2008; Tume et al., 2009). Moreover, inclusion of carotenoids source, for instance Spirulina, increased pigmentation level in the shell of $P$. monodon and Marsupenaeus japonicus, since shell pigmentation is sensitive with the dietary carotenoid (Liao et al., 1993; Chien \& Shiau, 2005).

Blue-green algae such as Spirulina contains carotenoids that are essential for crustaceans and fish. As fat-soluble pigments, the carotenoids, including astaxanthin, zeaxanthin and $\beta$-carotene are required for pigmentation and antioxidant activities, even though they cannot be synthesized by those animals. Thus, their dietary intake should consist of carotenoids (Boonyaratpalin et al., 2001; Wade et al., 2017). The concentration of the fatsoluble pigments might be varied (Table 1) in different species of Spirulina, however their main components of carotenoids are astaxanthin, zeaxanthin, and $\beta$-carotene (Liao et al., 1993; Chien \& Shiau 2005). In addition, Spirulina also contains protein, amino acids, vitamins, minerals and essential fatty acids such as $\gamma$-linolenic acid (GLA) (Belay et al., 1996). In order to accomplish the dietary requirements of carotenoids for the crustaceans, Spirulina can be included into their diets and be one of the ingredients in formulated feeds for shrimps, prawns and lobsters (Table 2). This inclusion increases not only body pigmentation, but also growth and survival rate (Liao et al., 1993; Chien \& Shiau, 2005; Tlusty et al., 2008; Pakravan et al., 2017).

Color has been used as an attribute to analyze various fields of study such as medical industry, chemistry, mobile robots and life sciences (Baykan et al., 2010; Wang et al., 2018). Moreover, in the last few decades, the computer technology can provide more consistent color definition of images obtained by digital cameras, cell phones or any other devices that could make analyzing digital images applicable (Tohda \& Gratzl, 2006; Gokay $\&$ Gundogdu, 2008). Color in digital image can be quantified using computer-aided image processing software which can represent the information into several color model such as RGB (red, green, blue), HSV (hue, saturation, value), CMYK (cyan, magenta, yellow, black) and L*a*b* (lightness, a* and $b^{*}$ for green-red and blue-yellow color components). Among them, the $\mathrm{L}^{*} \mathrm{a}^{*} \mathrm{~b}^{*}$ model has the largest spectrum covering all color in the RGB and CMYK. However, the HSV color model could describe the way human eye experience color sensation better than the RGB color model does (Yam \& Papadakis, 2004; Chen \& Wu, 2005).

Hue, saturation, and value/brightness can accurately define the color of the object. These three color parameters are adequate to determine one color from other observed colors (Camgöz et al., 2002). In this HSV color mode, hue describes what a pure color (pure red, yellow, or orange) is. Hue refers to the perceived color (technically, the dominant wavelength) that varies from 0 to $360^{\circ}$. Saturation presenting the degree of which color is diluted by white light, giving rise the terms of "light" and "dark" in a color. Higher values in the saturation make the color appear stronger, while lower values (tending to black) make the color 
Oseanologi dan Limnologi di Indonesia 2019 4(2):101-112

appear much washed out (ranges from 0 to $100 \%$ ). As value, brightness, varies from $0-100$ percent, works in conjunction with saturation and describes the amount of light or power of the source of the color, where 0 is completely black, and 100 is the brightest and reveals the most color (Chen $\& \mathrm{Wu}$, 2005; Cattin, 2016).

As previously stated that color alteration from black or highly pigmented into pale or white also occurs in spiny lobster and potentially affects $\$ 10-\$ 15$ of Panulirus homarus market value (ACIAR, 2009). Therefore, the aim of this study is to examine the effect of Spirulina inclusion in the artificial feed of juvenile spiny lobster $P$. homarus to its body color alteration with regard to HSV color perception. The HSV color model is performed to describe the color sensation that is close to human perception.

Table 1. Carotenoids levels in Spirulina.

Tabel 1. Kandungan carotenoid pada Spirulina.

\begin{tabular}{|c|c|c|c|}
\hline Compounds & Species/Sources & Concentrations & References \\
\hline Astaxanthin & Spirulina subsalsa & $180 \mathrm{mg} / \mathrm{g}$ & Aakermann et al., 1992 \\
\hline \multirow[t]{2}{*}{ All-trans-zeaxanthin } & Spirulina powder & $0.09-0.69 \mathrm{mg} / \mathrm{g}$ & Park et al., 2018 \\
\hline & Spirulina platensis & $1.27 \mathrm{mg} / \mathrm{g}$ & Park et al., 2018 \\
\hline \multirow[t]{3}{*}{ Zeaxanthin } & Spirulina powder & $21 \mathrm{mg} / 100 \mathrm{~g}$ & Liao et al., 1993 \\
\hline & S. platensis & $6.65 \mathrm{mg} / \mathrm{g}$ & Ghaeni et al., 2015 \\
\hline & S. platensis & $310 \mathrm{mg} / \mathrm{g}$ & Aakermann et al., 1992 \\
\hline \multirow[t]{2}{*}{ Diatoxanthin } & Spirulina powder & $0.05-0.17 \mathrm{mg} / \mathrm{g}$ & Park et al., 2018 \\
\hline & S. platensis & $0.26 \mathrm{mg} / \mathrm{g}$ & Park et al., 2018 \\
\hline \multirow{2}{*}{ 13-cis- $\beta$-carotene } & Spirulina powder & $0-0.04 \mathrm{mg} / \mathrm{g}$ & Park et al., 2018 \\
\hline & S. platensis & $0.06 \mathrm{mg} / \mathrm{g}$ & Park et al., 2018 \\
\hline \multirow[t]{2}{*}{ 9-cis- $\beta$-carotene } & Spirulina powder & $0-0.25 \mathrm{mg} / \mathrm{g}$ & Park et al., 2018 \\
\hline & S. platensis & $0.38 \mathrm{mg} / \mathrm{g}$ & Park et al., 2018 \\
\hline \multirow[t]{2}{*}{ All-trans- $\beta$-carotene } & Spirulina powder & $0.02-0.72 \mathrm{mg} / \mathrm{g}$ & Park et al., 2018 \\
\hline & S. platensis & $2.30 \mathrm{mg} / \mathrm{g}$ & Park et al. 2018 \\
\hline \multirow[t]{4}{*}{$\beta$-carotene } & Spirulina powder & $52 \mathrm{mg} / 100 \mathrm{~g}$ & Liao et al., 1993 \\
\hline & S. platensis & $7.39 \mathrm{mg} / \mathrm{g}$ & Ghaeni et al., 2015 \\
\hline & S. platensis & $350 \mathrm{mg} / \mathrm{g}$ & Aakermann et al., 1992 \\
\hline & S. subsalsa & $320-640 \mathrm{mg} / \mathrm{g}$ & Aakermann et al. 1992 \\
\hline
\end{tabular}

Table 2. Spirulina inclusion studies in artificial feed for some commercial marine decapods.

Tabel 2. Penelitian tentang penggunaan Spirulina dalam pakan buatan pada beberapa decapoda laut komersial.

\begin{tabular}{lllll}
\hline References & Inclusion & Species & Response & $\begin{array}{l}\text { Response on } \\
\text { pigmentation }\end{array}$ \\
\hline Cuzon et al., 1981 & $3-8 \%$ & $\begin{array}{l}\text { Penaeus } \\
\text { japonicus }\end{array}$ & $\begin{array}{l}\text { Good growth and } \\
\text { survival rate }\end{array}$ & $\begin{array}{l}\text { More colored than those } \\
\text { fed without Spirulina }\end{array}$ \\
\hline Liao et al., 1993 & $1-5 \%$ & P. monodon & $\begin{array}{l}\text { Increase growth } \\
\text { rate at }<=1 \% \\
\text { concentration }\end{array}$ & $\begin{array}{l}\text { Color deeper, optimum } \\
\text { coloration in } 3 \% \\
\text { Spirulina }\end{array}$ \\
\hline Tlusty et al., 2005 & $6,3 \%$ & $\begin{array}{l}\text { Homarus } \\
\text { americanus }\end{array}$ & $\begin{array}{l}\text { Increase survival } \\
\text { rate }\end{array}$ & $\begin{array}{l}\text { Good pigmentation, pale } \\
\text { coloration performs in 0\% } \\
\text { Spirulina addition }\end{array}$ \\
\hline Tlusty et al., 2008 & $6,3 \%$ & H. americanus & $\begin{array}{l}\text { Increase survival } \\
\text { rate, decrease } \\
\text { disease incidence }\end{array}$ & - \\
\hline Pakravan et al., 2017 & $25 \%$ & $\begin{array}{l}\text { Litopenaeus } \\
\text { vannamei }\end{array}$ & $\begin{array}{l}\text { Increase survival } \\
\text { rate }\end{array}$ & - \\
\hline
\end{tabular}




\section{Methods}

This feeding trial study was conducted in Aquaculture Laboratory of the Research and Development Division for Marine Bio Industry Indonesian Institute of Sciences (LIPI), North Lombok, West Nusa Tenggara, Indonesia for 97 days (from 2 November 2016 to 7 February 2017). Wild captured transparent puerulus of spiny lobster $P$. homarus were collected from the fisherman in the southern part of Lombok, and then transferred into several indoor concrete tanks. Translucent puerulus were reared and fed ad libitum with minced trash fish once a day until they metamorphosed and molted into pigmented juveniles.

This study examined three replicates of three formulated feeds in the form of moist feed $(0 \%$ Spirulina, 4\% Spirulina and 8\% Spirulina) (Table 3.) and one replicate of natural feed (minced trash fish, TF). Ninety-six juveniles spiny lobster were employed for this feeding trial. The initial size of juveniles ranged between $0.45 \pm 0.08 \mathrm{~g}$ of body weight (BW), $0.82 \pm 0.04 \mathrm{~cm}$ of carapace length (CL) and $2.28 \pm 0.11 \mathrm{~cm}$ of total length (TL) (Table 4). Juveniles were randomly assigned into 10 rectangular semi-outdoor concrete tanks (10 lobsters/tank). The inner surfaces of those $800-\mathrm{L}$ rearing tanks were covered with white tiles.

The rearing tanks were cleaned and scrapped once a week and water regularly changed for up to $50 \%$ every two days. Water quality parameters such as salinity, temperature and $\mathrm{pH}$ were monitored daily between 31.4-32.8\%o, 26.7$28.5 \mathrm{n}^{\circ} \mathrm{C}$ and 8.29-8.45 respectively. Juveniles were fed once daily ad satiation in the morning after removal of uneaten feed and dirt. Bundles of black net and $\varnothing 1 / 2$ inch PVC tubes were used as a shelter to provide various hiding places during molting in each tank. Two aeration spots were also involved in each tank to supply adequate oxygen into the rearing water.

Juveniles were individually blot cloth to remove excess water, weighed and then photographed in a closed room to minimize natural light interferences at the beginning and the end of feeding trial. Semi-analytic digital scale [PS2100.R2, Radwag, Poland] was utilized to measure wet body weight (BW) of each lobster.
Then, growth performance parameters including specific growth rate (SGR) and percentage weight gain $(\% \mathrm{WG})$ in each treatment were determined according to Johnston et al. (2008) and Marchese et al. (2019). In addition, the percentage of survival rate (SR) was also estimated:

$$
\begin{aligned}
& S G R=\frac{\ln W_{f}-\ln W_{i}}{t} \times 100 \% \\
& W G=\frac{W_{f}-W_{i}}{W_{i}} \times 100 \%
\end{aligned}
$$

where $W_{f}$ is final weight $(\mathrm{g}) ; W_{i}$ is initial weight $(\mathrm{g})$; and $\mathrm{t}$ is number of days.

$$
S R=\frac{\text { final number of lobster }}{\text { initial number of lobster }} \times 100 \%
$$

Juveniles were individually placed dorsoventrally on a white graph paper on a copy stand equipped with adjustable light and mounted camera on top of it. Each picture was taken with the same condition of light (exposure, distance from the object, angle and intensity of the light source) using Canon 70D DSLR camera with 20, 20 megapixels resolution and $18-135 \mathrm{~mm}$ kit lens. Carapace length (CL) and total length (TL) were measured using image processing program ImageJ. Six points from two body areas (carapace and abdomen) (Figure 1) were scrutinized to value their pigmentation level (Tlusty, 2005) as HSV using Adobe Photoshop CC 2016.

\section{Statistical Analysis}

In this study, only formulated feed group that were analyzed statistically due to lack of replication in natural feed (trash fish, TF) treatment. Statistical program IBM SPSS Statistics 25.0 was employed for statistical analysis. Data were tested and transformed to meet ANOVA assumption such as normally distributed and homogenous variances using Shapiro-Wilk's and Levene's test. One-way ANOVA and Tukey's HSD post hoc test then were utilized to evaluate differences between treatments. For those data that didn't meet the assumption such as final total length, survival rate, saturation and brightness level of the eye spot, and hue level of the carapace, were tested through Kruskal-Wallis, with post hoc pairwise comparison Mann-Whitney. 
Table 3. Diet formulation ( $\%$ dry matter) of the moist diets.

Tabel 3. Formulasi pakan moist ( $\%$ bahan kering).

\begin{tabular}{|c|c|c|c|}
\hline \multirow{2}{*}{ Ingredients } & \multicolumn{3}{|c|}{ Diets } \\
\hline & $0 \%$ & $4 \%$ & $8 \%$ \\
\hline Corn starch ${ }^{1}$ & 5 & 5 & 5 \\
\hline Wheat flour ${ }^{2}$ & 10 & 10 & 10 \\
\hline Soybean lecithin & 2 & 2 & 2 \\
\hline $\mathrm{Oil}^{3}$ & 2 & 2 & 2 \\
\hline Meat and bone meal & 17 & 17 & 17 \\
\hline Fish meal & 25 & 25 & 25 \\
\hline Vitamin and mineral mix ${ }^{4}$ & 3 & 3 & 3 \\
\hline$\alpha$-cellulose & 8 & 4 & 0 \\
\hline Spirulina powder ${ }^{5}$ & 0 & 4 & 8 \\
\hline Trash fish ${ }^{6 *}$ & 117 & 117 & 117 \\
\hline
\end{tabular}

${ }^{1}$ Maizenaku (Ega Food, West Jakarta, Jakarta, Indonesia)

${ }^{2}$ Lencana Merah (PT. ISM Bogasari Flour Mills, North Jakarta, Jakarta, Indonesia)

${ }^{3}$ Bimoli (PT. Indofood Sukses Makmur Tbk., South Jakarta, Jakarta, Indonesia)

${ }^{4}$ Caviplex (PT. Erlangga Edi Laboratories, Semarang, Central Java, Indonesia)

${ }^{5}$ Mackay Marine Microfine Spirulina (Mackay Marine Brine Shrimp Co)

${ }^{6}$ Frozen fish from the local fisherman (Sardinella spp.)

*Wet basis

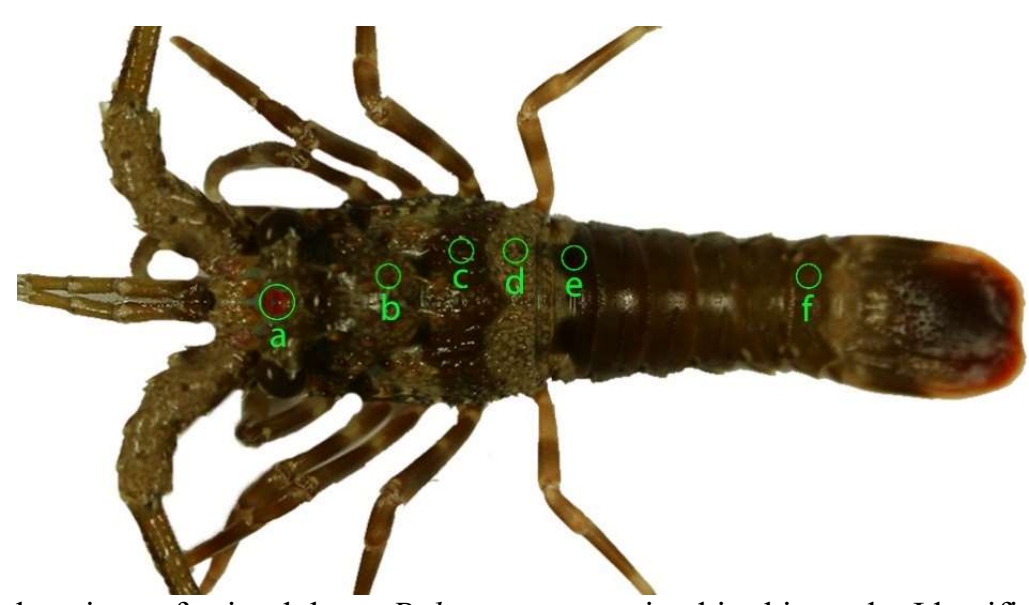

Figure 1. Six body locations of spiny lobster $P$. homarus examined in this study. Identified locations include a) red spot between eye stalks, b) carapace cranial medial, c) black strip of carapace caudal medial, d) white strip of carapace caudal medial, e) first abdominal segment, f) last abdominal segment.

Gambar 1. Enam titik bagian tubuh lobster pasir P. homarus yang dianalisis. Lokasi tersebut, yaitu a) titik merah di antara kedua tangkai mata, b) karapas kranial medial, c) pita hitam pada karapas caudal medial, d) pita putih pada karapas caudal medial, e) segmen abdomen pertama, f) segmen abdomen terkahir.

\section{Results}

In this study, no significant differences were detected $(P<0.05)$ in mean body size, such as body weight (WG) and carapace length, and growth performances, for instance specific growth rate (SGR) and weight gain of spiny lobster P. homarus juveniles among the formulated diet treatments. However, 0\% Spirulina had the highest mean for SGR and WG among the formulated diets treatments. In contrast, trash fish (TF) treatment had the highest SGR and WG when compared to three formulated diets. Trash fish gave 1.22 and 1.36 times larger than $0 \%$ Spirulina formulated diet treatments for SGR and WG, respectively. There were also no significant difference on survival rate of spiny lobster among formulated diet treatments. However, survival rate of spiny lobster fed with $4 \%$ Spirulina diet tended to be higher compared to other formulated diets and trash fish diet as well. 


\section{Soffa et al.}

On the other hand, the numerically lowest survival rate was found in the spiny lobster fed with trash fish (Table 4).

On the question of body color change, each feeding treatment significantly altered $(P<0.05)$ body color in six different body parts for 97 days feeding trial, but no significant differences $(P<$ 0.05 ) were observed among formulated diet treatments. Hue level significantly decreased during feeding trial, except for the carapace anterior that significantly increased. In addition, saturation level also displayed similar trend with hue level that significantly declined, but no significant differences for the white strip on carapace. Moreover, trash fish produced the lowest saturation level when compared with all feeding treatments. With regard to brightness level, it demonstrated contrasting trend from other parameters that were mentioned earlier. Brightness level significantly raised after 97 days of feeding period. However, trash fish gave the highest brightness level among the feeding treatments (Figure 2 and 3).

Table 4. Growth and survival rate of $P$. homarus juveniles fed formulated and trash fish diets that contained different Spirulina concentration.

Tabel 4. Laju pertumbuhan dan kelangsungan hidup juvenil $P$. homarus yang diberi pakan ikan rucah dan pakan formulasi pada kandungan Spirulina yang berbeda.

\begin{tabular}{lcccc}
\hline \multirow{2}{*}{ Parameter } & \multicolumn{3}{c}{ Spirulina } & Trash Fish \\
\cline { 2 - 4 } & $0 \%$ & $4 \%$ & $8 \%$ & \\
\hline Initial weight $(\mathrm{g})$ & $0.44 \pm 0.05$ & $0.44 \pm 0.07$ & $0.44 \pm 0.04$ & $0.56 \pm 0.05$ \\
Final weight $(\mathrm{g})$ & $3.06 \pm 0.04^{*}$ & $2.84 \pm 0.65^{*}$ & $2.78 \pm 0.41^{*}$ & $5.24 \pm 1.20$ \\
\hline Initial carapace length $(\mathrm{cm})$ & $0.82 \pm 0.01$ & $0.82 \pm 0.04$ & $0.81 \pm 0.02$ & $0.90 \pm 0.03$ \\
Final carapace length $(\mathrm{cm})$ & $1.48 \pm 0.03^{*}$ & $1.47 \pm 0.13^{*}$ & $1.44 \pm 0.08^{*}$ & $1.85 \pm 0.13$ \\
\hline Initial total length $(\mathrm{cm})$ & $2.28 \pm 0.04$ & $2.26 \pm 0.09$ & $2.24 \pm 0.05$ & $2.47 \pm 0.07$ \\
Final total length $(\mathrm{cm})$ & $4.14 \pm 0.07^{*}$ & $4.04 \pm 0.34^{*}$ & $3.99 \pm 0.20^{*}$ & $5.01 \pm 0.41$ \\
\hline Specific growth rate & $2.02 \pm 0.11$ & $1.89 \pm 0.12$ & $1.87 \pm 0.20$ & 2.47 \\
Weight gain $(\%)$ & $615.35 \pm 74.35$ & $530.91 \pm 66.50$ & $540.29 \pm 131.34$ & 840.75 \\
Survival rate (\%) & $51.85 \pm 1.85$ & $53.33 \pm 12.02$ & $48.52 \pm 9.35$ & 20.00 \\
\hline
\end{tabular}

Significant differences of the final means with the initial means within the same measurement in the same column are indicated by asterisk $(P<0.05)$. Significant differences between means within the similar row are indicated by different letters in superscripts $(P<0.05)$. Data that are shown in italic, were not analyzed due to lack of replicates.

Significant differences in response to feed treatment in each body part are marked with upper case letters (a, $\mathrm{b}$, ab) $(P<0.05)$. Significant differences of the final means with the initial means in each body part are marked with asterisk $\left(^{*}\right)(P<0.05)$. Trash fish (TF) data were not analyzed due to lack of replicates. 
Oseanologi dan Limnologi di Indonesia 2019 4(2):101-112
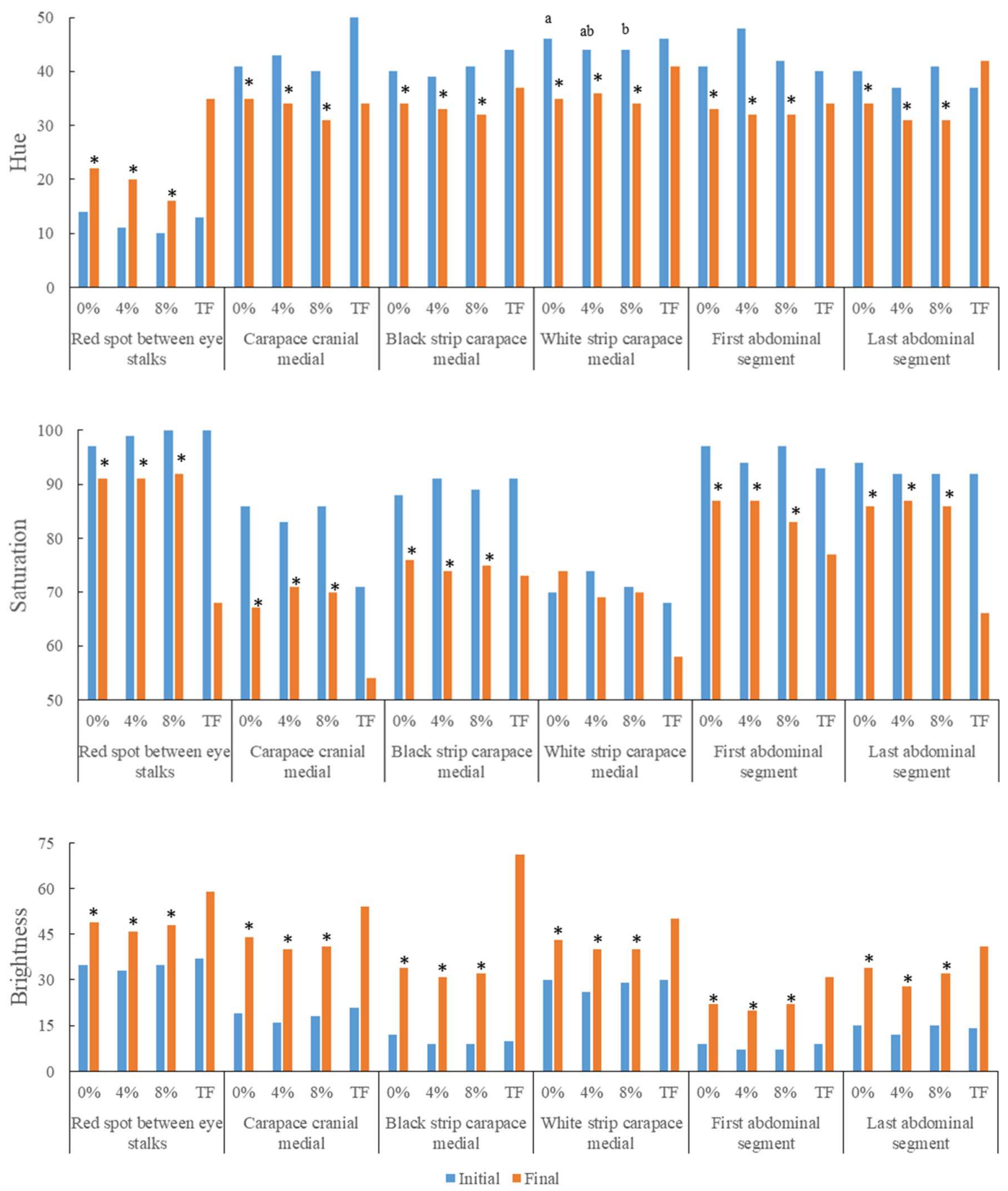

Figure 2. Differences in three color parameter levels of $P$. homarus juveniles at four treatments $(0 \%, 4 \%$ and $8 \%$ Spirulina powder, and trash fish (TF)) at six body parts.

Gambar 2. Perbedaan tiga parameter warna dari juvenile $P$. homarus di keempat perlakuan $(0 \%, 4 \%$ and $8 \%$ serbuk Spirulina, dan ikan rucah (TF)) pada enam bagian tubuh. 


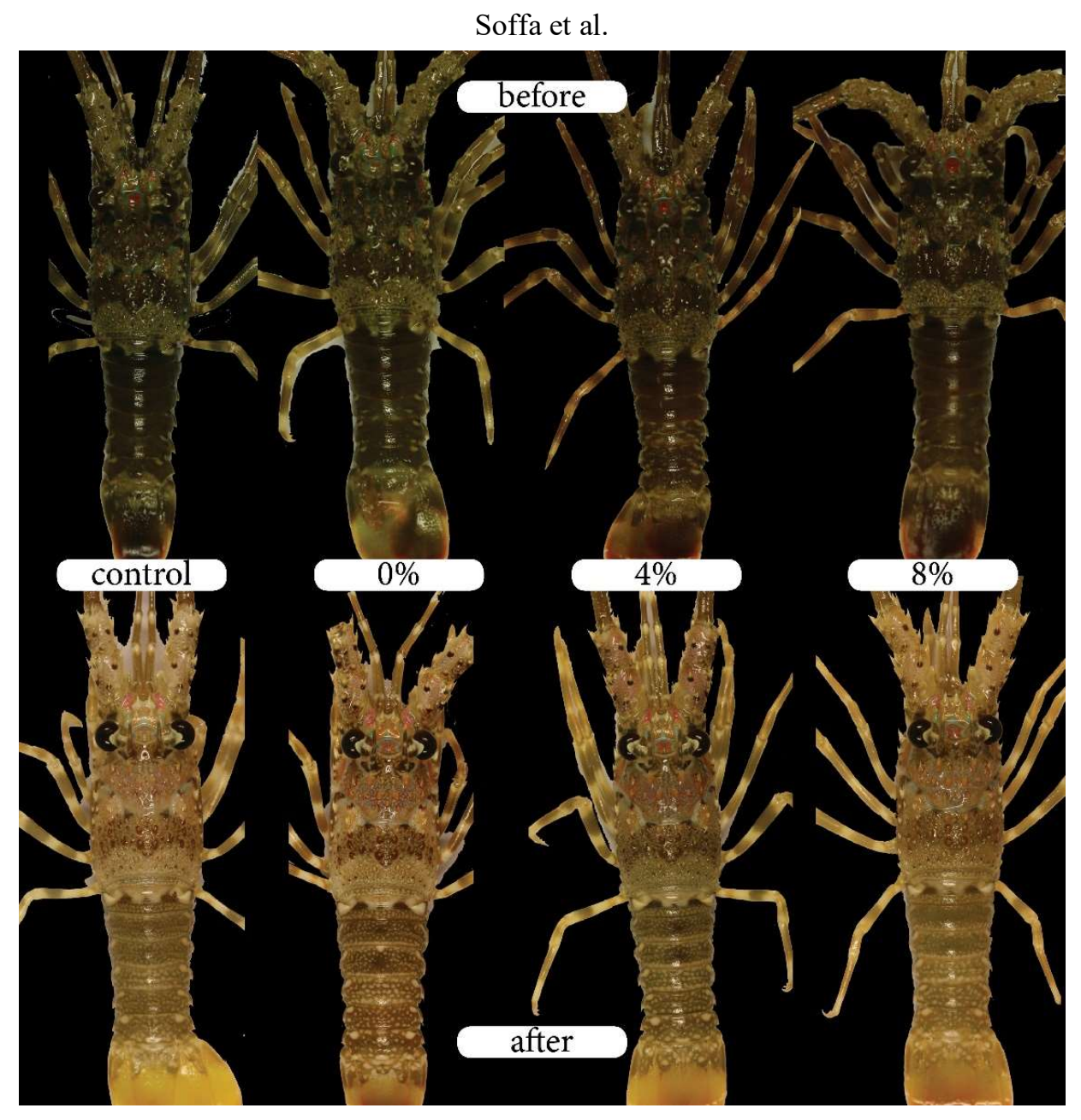

Figure 3. The body color of spiny lobster juvenile before (above) and after (below) 97 days of feeding trial, a) control, b) formulated diet with $0 \%$ Spirulina, c) formulated diet with $4 \%$ Spirulina, d) formulated diet with $8 \%$ Spirulina.

Gambar 3. Warna tubuh juvenil lobster pasir pada kondisi sebelum (baris atas) dan sesudah (baris bawah) perlakuan pakan selama 97 hari, a) kontrol/ikan rucah, b) pakan formulasi dengan 0\% Spirulina, c) pakan formulasi dengan 4\% Spirulina, d) pakan formulasi dengan $8 \%$ Spirulina.

\section{Discussion}

In general, color of the most body parts of the experimented lobsters significantly decreased in hue and saturation but increased in value/brightness. Human eyes would experience a different color appearance from "dark brown" to "light brown" due to this HSV value changes. Though, this perception is related with the background color that make object look pale if the background has a complementary color with the object (Ang, 2012). In HSV color model, hue is the main parameter that represent the visual experiences in a single character (Cantrell et al., 2010). Decreasing level of hue on 5 body parts could means that the spiny lobster juvenile emits different wavelength of light, make them appear slightly reddish, and also a bit lighter in response of the drop of saturation. Meanwhile, the increasing level of value or brightness in all body parts reveals the true color of their body and makes it look brighter. This color alteration occur due to the bathochromic shift of the absorption by astaxanthin in lobster crustacyanin, which absorbed a short wavelength (violet, blue, green) and emitted it into a longer wavelength (yellow, orange, red) (Cianci et al., 2002; Parisenti et al., 2011).

Carotenoid, dominantly astaxanthin, are liposoluble pigments that responsible for the coloration of crustaceans (Goodwin, 1984; Liao et al., 1993; Astorg, 1997; Milani et al., 2017). In this study, with regard to carotenoids content in Spirulina, we found the opposite results with the previous research that Spirulina-addition diet drive to a better coloration for several crustaceans, such as $P$. japonicus, $P$. monodon, $H$. americanus and $L$. vannamei (Table 2 ). These contrary results might 


\section{Oseanologi dan Limnologi di Indonesia 2019 4(2):101-112}

occur due to the difficulty to maintain pigmentation level in crustaceans. The initial body color could be hard to maintain even with the addition of carotenoids or astaxanthin in the diet due to the variation of the required carotenoid concentration which they express (greater or lesser) depend on their environments (Menasveta et al., 1993; Pan et al., 2001; Chien \& Shiau 2005; Diaz-Jimenez et al., 2018). Another factor that play the important role in this coloration issue is light exposure as result of the semi-outdoor experimental tank that illuminated by indirect natural daylight. Moreover, white-tiles-cover in tank inner surfaces would reflecting light and could illuminating the lobster even when they hide in their shelter. You et al. (2006) observed that the reflecting-light substrate could generate the aggregation of astaxanthin in shrimp as a defense mechanism to protect their body from any damage cause by luminosity excess. Furthermore, utilizing white color tiles as a background could trigger their color-match ability in order to disguise themselves from predators, which is commonly found in many crustacean species including shrimps, prawns, and crabs (Parisenti et al., 2011; Russel \& Dierssen, 2015; Duarte et al., 2017; Diaz-Jimenez et al., 2018).

In this study, inclusion up to $8 \%$ of Spirulina in the diet did not affect growth performance of $P$. homarus. However, inclusion of Spirulina in the diet tended to decrease growth performance in the present study. This finding was similar with Liao et al. (1993) who found that inclusion more than 3\% of Spirulina in the diet decreased body weight of black tiger prawn, $P$. monodon. In contrast, the positive effect of inclusion of Spirulina on the growth performance have been recorded in kuruna prawn Marsupenaeus japonicus and shrimp Fenneropenaeus chinesis particularly when Spirulina was included in the low amounts in the diet (Chien \& Shiau, 2005; Kim et al., 2006). Therefore, it could be referred that the excessive inclusion level of Spirulina in the diet retard growth performance of spiny lobster in this study. In the other hand, SGR and WG of spiny lobster fed with trash fish diet was higher than formulated diets in this study. The possible reasons were due to the food handling technique. In this study, the moist feeds were stored in freezer and then thawed every day. During this frozen and thawed process, nutrient contents in formulated feed such as vitamins may deteriorate, and thus nutrition values decrease (Barclay et al., 2006). Another factor that can contribute to low growth rate in the formulated diets is the formulated diet itself. Previous study has revealed that formulated feed could exacerbate the effort of digestion and nutrients absorption in $P$. homarus which reduce energy budget to grow.
In contrast, natural feed reduces those effort and increase energy deposit into body mass (Gora et al., 2018). Thus, trash fish, in this study, had the highest SGR and WG among the feeding treatments.

With respect to survival rate, the $4 \%$ Spirulina inclusion was numerically higher than control and $8 \%$ Spirulina. It has been known that carotenoid compounds in the Spirulina might increase antioxidant activities and then decreased stress level in the white shrimp Litopenaeus vannamei and prawn P. monodon (Pakravan et al., 2017; Wade et al., 2017). Therefore, high survival rate in spiny lobster fed with $4 \%$ Spirulina might be associated with increasing those activities. In addition, survival rate of lobster fed by the artificial feed in this study is higher than trash fish-fed lobster. Current finding was similar with previous study with tropical spiny lobster Panulirus ornatus. The spiny lobster that were fed with artificial feed or astaxanthin inclusion in artificial feed had better survival rate than when fed with natural feed, such as blue mussel and green mussel because natural feed inadequate to satisfy nutritional requirement of the spiny lobster (Smith et al., 2005; Barclay et al., 2006).

\section{Conclusion}

In conclusion, color alteration in the body parts of juvenile $P$. homarus from strong color into pale were detected during 97 days rearing period. Moreover, inclusion up to $8 \%$ of Spirulina in the formulated feed did not increase pigmentation levels in the carapace and abdomen of juvenile $P$. homarus. In addition, growth performance of juvenile $P$. homarus were not also influenced by inclusion of Spirulina in the formulated feed. However, survival rate of $P$. homarus fed with formulated feed supplemented with Spirulina were higher than trash fish diet. From this findings, further investigations are needed to evaluate inclusion of another carotenoid sources in the formulated diet and/ in combination with different environmental factors to retain and increase pigmentation level of juvenile $P$. homarus in the captivity.

\section{Acknowledgement}

This work was financially supported by the Indonesian Institute of Sciences (LIPI) as part of DIPA 2016 of the Research and Development Division for Marine Bio Industry, LIPI. The authors would like to express sincere gratitude to the technical supports to La Ali for the water quality measurements, Syafriadi Hafid, Djunaidi 
Soffa et al.

and Syakirin for the animal body measurements and animal husbandry, and other anonymous reviewers whose constructive criticism helped to strengthen this manuscript.

\section{References}

Aakermann, T., Skulberg, O. M., \& Liaaen-Jensen, S. (1992). A comparison of the carotenoids of strains of Oscillatoria and Spirulina (Cyanobacteria). Biochmeical Systematics and Ecology, 20(8), 761-769.

ACIAR. (2009). Final report: Assessing the SouthEast Asian tropical lobster supply and major market demands. Australian Center for International Agricultural Research, Canberra. p. 33.

Ang T. (2012). Digital photographer's handbook. Fully updated $5^{\text {th }}$ edition. DK Publishing. New York. 408 pp.

Astorg P. (1997). Food carotenoids and cancer prevention: An overview of current research. Trends Food Science Technology, 18, 406-413.

Barclay, M. C., Irvin, S. J., Williams, K. C. \& Smith, D.M. (2006). Comparison of diets for the tropical spiny lobster Panulirus ornatus: Astaxanthin-supplemented feeds and mussel flesh. Aquaculture Nutrition, 12, 117-125.

Baykan, N. A., Yilmaz, N. \& Kansun, G. (2010). Case study in effects of color spaces for mineral identification. Scientific Research and Essays, 5(11), 1243-1253.

Belay, A., Kato, T. \& Ota, Y. (1996). Spirulina (Arthrospira): Potential application as an animal feed supplement. Journal of Applied Phycology, 8, 303-311.

Boonyaratpalin, M., Thongrod, S., Supamattaya, K., Britton, G. \& Schlipalius, L. E. (2001). Effects of $\beta$-carotene source, Dunaliella salina, and astaxanthin on pigmentation, growth, survival and health of Penaeus monodon. Aquaculture Research, 32, 182190.

Camgöz, N., Yener, C., \& Güvenç, D. (2002). Effects of hue, saturation, and brightness on preference. Color Research and Application, 27(3), 199-207.

Cantrell, K., Erenas, M. M., de Orbe-Paya, I., \& Capitan-Vallvey, L. F. (2010). Use of the hue parameter of the hue, saturation, value color space as a quantitative analytical parameter for bitonal optical sensors. Analytical Chemistry, $82,531-542$.

Cattin, P. (2016). Digital image fundamentals: Introduction to signal and image processing. Retrieved from https://miac.unibas.ch/SIP/02Fundamentals.html\#(1)
Chen, C., \& Wu, W. (2005). Color pattern recognition with the multi-channel non-zero-order joint transform correlator based on the HSV color space. Optics Communications, 244, 51-59.

Chien, Y., \& Shiau, W. (2005). The effects of dietary supplementation of algae and synthetic astaxanthin on body astaxanthin, survival, growth, and low dissolved oxygen stress resistance of kuruma prawn, Marsupenaeus japonicus Bate. Journal of Experimental Marine Biology and Ecology, 318(2), 201-211.

Cianci, M., Rizkallah, P. J., Olczak, A., Raftery, J., Chayen, N. E., Zagalsky, P. F., \& Helliwell, J. R. (2002). The molecular basis of the coloration mechanism in lobster shell: $\beta$ Crustacyanin at 3.2- $\AA$ resolution. Proceedings of the National Academy of Sciences of the United States of America (PNAS), 99(15), 9795-9800.

Cuzon, G., Santos, R. D., Hew, M., \& Poullaouec, G. (1981). Use of Spirulina in shrimp (Penaeus japonicas) diet. J. World Maricul. Soc., 12(2), 282-291.

D'abramo, L. R., Baum, N. A., Bordner, C. E., \& Conklin, D. E. (1983). Carotenoids as a source of pigmentation in juvenile lobsters fed a purified diet. Canadian Journal of Fisheries and Aquatic Sciences, 40, 699704.

Diaz-Jimenez. J., Hernandez-Vergara, M. P., \& Perez-Rostro, C. I. (2018). The effect of background colour and lighting of the aquarium on the body pigmentation of the peppered shrimp Lysmata wurdemanni. Aquaculture Research, 49, 3508-3516.

Duarte, R. C., Flores, A. A. V., Vinagre, C., \& Leal, M. C. (2017). Habitat-dependent niche partitioning between colour morphs of the algal-dwelling shrimp Hippolyte obliquimanus. Marine Biology, 164, 215.

Ghaeni, M., Roomiani, L., \& Moradi, Y. (2015). Evaluation of carotenoids and chlorophyll as natural resources for food in Spirulina microalgae. Applied Food Biotechnology, 2(1), 39-44.

Gokay, M. K., \& Gundogdu, I. B. (2008). Color identification of some Turkish marbles. Construction and Building Materials, 22, 1342-1349.

Goodwin, T. W. (1984). The biochemistry of the carotenoids, volume II Animals. $2^{\text {nd }}$ edition. Chapman and Hall, London. 213 pp.

Gora, A., Jayasankar, V., Rehman, S., Kizhakudan, J. K., Laxmilatha, P., \& Vijayagopal, P. (2018). Biochemical responses of juvenile rock spiny lobster Panulirus homarus under different 


\section{Oseanologi dan Limnologi di Indonesia 2019 4(2):101-112}

feeding regimes. Journal of Applied Animal Research, 46(1), 1461-1468.

Johnston, D., Melville-Smith, R., Hendriks, B., \& Phillips, B. (2008). Growth rates and survival of western rock lobster (Panulirus cygnus) at two temperatures (ambient and 23 $\left.{ }^{\circ} \mathrm{C}\right)$ and two feeding frequencies. Aquaculture, 279, 77-84.

Kim, C. J., Yoon, S. K., Kim, H. I., Park, Y. H., \& Oh, H. M. (2006). Effect of Spirulina platensis and probiotics as feed additives on growth of shrimp Fenneropeaeus chinensis. J. Microbiol. Biotechnol., 16(8): 1248-1254.

Liao, W., Nur-E-Bohran, S. A., Okada, S., Matsui, T., \& Yamaguchi, K. (1993). Pigmentation of cultured black tiger prawn by feeding with a Spirulina-supplemented diet. Nippon Suisan Gakkaishi, 59(1), 165-169.

Marchese, G., Fitzgibbon, Q. P., Trotter, A. J., Carter, C. G., Jones, C. M., \& Smith, G. G. (2019). The influence of flesh ingredients format and krill meal in growth and feeding behavior of juvenile tropical spiny lobster, Panulirus ornatus. Aquaculture, 499, 128139.

Melville-Smith, R., Cheng, Y. W., \& Thomson, A. W. (2003). Factors affecting colour change in 'white' western rock lobsters, Panulirus cygnus. Journal of Experimental Marine Biology and Ecology, 291, 111-129.

Menasveta, P., Worawattanamateekul, W., Latscha, T., \& Clark, J. S. (1993). Correction of black tiger prawn (Penaeus monodon Fabricius) coloration by astaxanthin. Aquacultural Engineering, 12, 203-213.

Milani, A., Basimejad, M., Shahbazi, S., \& Bolhassani, A. (2017). Carotenoids: Biochemistry, pharmacology and treatment. British Journal of Pharmacology, 174, 12901324.

Pakravan, S., Akbarzadeh, A., Sajjadi, M. M., Hajimoradloo, A., \& Noori, F. (2017). Partial and total replacement of fish meal by marine microalga Spirulina platensis in the diet of Pacific white shrimp Litopenaeus vannamei: Growth, digestive enzyme activities, fatty acid composition and responses to ammonia and hypoxia stress. Aquaculture Research, 48, 5576-5586.

Pan, C., Chien, Y., \& Cheng, J. (2001). Effects of light regime, algae in the water, and dietary astaxanthin on pigmentation, growth, and survival of black tiger prawn Penaeus monodon post-larvae. Zoological Studies, 40(4), 371-382.

Parisenti, J., Beirão, L. H., Mouriňo, J. L., Vieira, F. N., Buglione, C. C., \& Maraschim, M.
(2011). Effect of background color on shrimp pigmentation. Boletim do Instituto de Pesca, 37(2), 177-182.

Park, W. S., Kim, H., Li, M., Lim, D. H., Kim, J., Kwak, S., Kang, C., Feruzzi, M. G., \& Ahn, M. (2018). Two classes of pigments, carotenoids and c-phycocyanin, in Spirulina powder and their antioxidant activities. Molecules, 23, 2065-2075.

Rao, K. R. (2001). Crustacean pigmentary-effector hormones: Chemistry and functions of RPCH, PDH, and related peptides. American Zoologist, 41, 364-379.

Russel, B. J., \& Dierssen, H. M. (2015). Use of hyperspectral imagery to assess cryptic color matching in Sargassum associated crabs. PLOS $O N E$. | doi:10.1371/journal.pone.0136260.

Smith, D. M., Williams, K. C., \& Irvin, S. J. (2005). Response of the tropical spiny lobster Panulirus ornatus to protein content of pelleted feed and to a diet of mussel flesh. Aquaculture Nutrition, 11, 209-217.

Tlusty, M. F. (2005). Use of digital colour analysis to assess variation within individual adult American lobsters (Homarus americanus) and the process of addition of colour in white lobsters. New Zealand Journal of Marine and Freshwater Research, 39, 571-580.

Tlusty, M. F., Goldstein, J. S., \& Fiore, D. R. (2005). Hatchery performance of early benthic juvenile American lobsters (Homarus americanus) fed enriched frozen adult Artemia diets. Aquaculture Nutrition, 11, 191-198.

Tlusty, M. F., Myers, A., \& Metzler, A. (2008). Short- and long-term dietary effects on disease and mortality in American lobster, Homarus americanus. Diseases of Aquatic Organisms, 78, 249-253.

Tohda, K., \& Gratzl, M. (2006). Micro-miniature autonomous optical sensor array for monitoring ions and metabolites 1: Design, fabrication, and data analysis. Analytical Sciences, 22, 383-388.

Tseng, K., Su, H., \& Su, M. (1998). Culture of Penaeus monodon in a recirculating system. Aquacultural Engineering, 17, 138-147.

Tume, R. K., Sikes, A. L., Tabrett, S., \& Smith, D. M. (2009). Effect of background colour on the distribution of astaxanthin in black tiger prawn (Penaeus monodon): Effective method for improvement of cooked colour. Aquaculture, 296, 129-135.

Wade, N. M., Melville-Smith, R., Degnan, B. M., \& Hall, M. R. (2008). Control of shell colour changes in the lobster, Panulirus cygnus. The 
Soffa et al.

Journal of Experimental Biology, 211, 15121519.

Wade, N. M., Anderson, M., Sellars, M. J., Tume, R. K., Preston, N. P., \& Glencross, B. D. (2012). Mechanisms of colour adaptation in the prawn Penaeus monodon. Journal of Experimental Biology, 215, 343-350.

Wade, N. M., Gabaudan, J., \& Glencross, B. D. (2017). A review of carotenoid utilisation and function in crustacean aquaculture. Reviews in Aquaculture, 9, 141-156.

Wang, Y., Liu, Y., Liu, W., Tang, W., Shen, L., Li, Z., \& Fan, M. (2018). Quantification of combined color and shade changes in colorimetry and image analysis: Water $\mathrm{pH}$ measurement as an example. Analytical Methods. The Royal Society of Chemistry, 10, 3059-3065.

Yam, K. L., \& Papadakis, S. E. (2004). A simple digital imaging method for measuring and analyzing color of food surfaces. Journal of Food Engineering, 61(1), 137-142.

You, K., Yang, H., Liu, Y., Liu, S., Zhou. Y., \& Zhang, T. (2006). Effects of different light sources and illumination methods on growth and body color of shrimp, Litopenaeus vannamei. Aquaculture, 252, 557-565. 